http://dx.doi.org/10.18778/1429-3730.51.04

\author{
dr hab. Dorota Teneta-Skwiercz*
}

\title{
ODPOWIEDZIALNA KONSUMPCJA W ŚWIETLE WYNIKÓW BADAŃ
}

\author{
RESPONSIBLE CONSUMPTION IN THE LIGHT \\ OF RESEARCH RESULTS
}

\begin{abstract}
The aim of the article was to identify attitudes towards the protection of the natural environment and practices of pro-environmental activities. The study attempted to answer the following questions: What is the level of ecological awareness of respondents? In particular, do they have ecological knowledge and imagination? What is their sense of agency in the area of individually undertaken actions for the benefit of the environment? What are the most important criteria for shopping? What is the position of pro-environmental and pro-social criteria in this collection? What kind of environmental activities are taken by respondents in their daily lives?

To answer the above questions, a survey was conducted directly from primary sources among students of three faculties of the University of Economics in Wroclaw. Studies have shown that respondents are characterized by an average level of ecological awareness, while in men the level of this awareness, as well as the sense of efficiency of individual pro-ecological activities, are slightly lower than in women. Both surveyed women and men similarly prioritize the criteria for purchasing products. The pro-environmental criteria are perceived by them as less important. There were no significant differences between men and women in the field of activities undertaken for the benefit of the environment.
\end{abstract}

Keywords: Responsible consumption, sustainable development, ecological awareness

JEL classification: $013, \mathrm{Q} 56$

* Uniwersytet Ekonomiczny we Wrocławiu, Wydział Nauk Ekonomicznych, Katedra Ekonomiki i Organizacji Przedsiębiorstwa; alley77@poczta.onet.pl 


\section{Wstęp}

Wielu autorów zwraca uwagę, iż obecnie mamy do czynienia ze zjawiskiem nadmiernej konsumpcji, która prowadzi do marnotrawstwa wyprodukowanych dóbr (nadprodukcja), degradacji środowiska naturalnego, zwiększania dysproporcji w społeczeństwie, sukcesywnego niszczenia nieodnawialnych zasobów naturalnych ${ }^{1}$. Międzynarodowe organizacje rządowe, takie jak Komisja Zrównoważonego Rozwoju ONZ, Organizacja Współpracy Gospodarczej i Rozwoju oraz Program Środowiskowy Organizacji Narodów Zjednoczonych, zwróciły uwagę na kwestię zrównoważonej (odpowiedzialnej) konsumpcji. Nadmierne konsumowanie i niezrównoważone wzorce konsumpcji gospodarstw domowych, dominujące zwłaszcza w krajach uprzemysłowionych i rozwiniętych, zostały przez nie uznane za główne czynniki powodujące wyczerpywanie zasobów i degradację środowiska $^{2}$ oraz przeszkody dla zrównoważonego rozwoju.

Nie dziwi zatem fakt, iż od kilku lat jesteśmy świadkami dekonsumpcji, tj. świadomego ograniczania wolumenu nabywanych dóbr. Przyczyn tego trendu można upatrywać w takich zjawiskach jak:

- wzrost niepewności sytuacji współczesnych gospodarstw domowych (konsumpcja asekuracyjna),

- zwiększanie aspiracji jakościowych,

- rezygnacja z konsumpcji w sferze materialnej na rzecz sfery niematerialnej,

- wzrost racjonalizacji konsumpcji3 .

Rozbudzonej świadomości ekologicznej towarzyszy potrzeba konsumpcji zrównoważonej. W praktyce oznacza to fundamentalne zmiany w zakresie stosowanych modeli biznesowych, w sposobie wytwarzania i konsumowania dóbr.

Celem niniejszego opracowania jest identyfikacja postaw wobec ochrony środowiska naturalnego oraz praktykowanych działań prośrodowiskowych ${ }^{4}$. Realizacji tak sformułowanego celu służyły badania sondażowe bezpośrednie ze źródeł pierwotnych, wśród studentów trzech wydziałów Uniwersytetu Ekonomicznego we Wrocławiu.

${ }^{1}$ S. Tkaczyk, J. Kołuda, Nowe trendy konsumenckie a sukces organizacji, „Zeszyty Naukowe Uniwersytetu Przyrodniczo-Humanistycznego w Siedlcach”, nr 97, Seria: Administracja i Zarządzanie 2013, nr 24, s. 24.

${ }^{2}$ UNEP, Planning for Change: Guidelines for national programmes on sustainable consumption and production. United Nations Environment Programme 2008.

${ }^{3}$ Cz. Bywalec, L. Rudnicki, Konsumpcja, Polskie Wydawnictwo Ekonomiczne, Warszawa 2002, s. $140-141$.

${ }^{4}$ Autorka niniejszego artykułu działalność „prośrodowiskową” rozumie szeroko, jako działania na rzecz środowiska zarówno społecznego, jak i naturalnego. 


\section{Istota odpowiedzialnej konsumpcji}

Odpowiedzialną konsumpcję można zdefiniować jako „korzystanie z usług i związanych z nimi produktów, które odpowiadają na podstawowe potrzeby i przynoszą lepszą jakość życia przy jednoczesnej minimalizacji wykorzystania zasobów naturalnych i toksycznych materiałów, a także emisji odpadów i zanieczyszczeń w całym cyklu życia usługi lub produktu tak, aby nie ograniczać przyszłym pokoleniom możliwości zaspokajania potrzeb"s. F. Bylok wyjaśnia istotę odpowiedzialnej konsumpcji przez pryzmat trzech zasad: racjonalności ekonomicznej, tj. optymalizacji ekonomicznej w wyborze dóbr, racjonalności ekologicznej, rozumianej jako wybór takich dóbr, które w najmniejszym stopniu szkodzą środowisku oraz racjonalności społecznej, sprowadzającej się do wyboru dóbr, które rozwiązują problemy społeczne lub przynajmniej nie przyczyniają się do ich pogłębienia ${ }^{6}$. Analiza przytoczonych definicji prowadzi do konstatacji, iż podstawowymi atrybutami odpowiedzialnej konsumpcji są: nacisk na zaspokajanie potrzeb o charakterze podstawowym, dążenie do poprawy jakości życia oraz dbałość o stan środowiska naturalnego, wyrażająca się racjonalnym wykorzystaniem zasobów naturalnych oraz unikaniem marnotrawstwa w całym cyklu życia produktu.

Zasadniczą rolę w zakresie kształtowania postaw i zachowań w odniesieniu do środowiska naturalnego odgrywa świadomość ekologiczna. W literaturze przedmiotu nie ma jednej uniwersalnej definicji tego pojęcia. P. Sztompka definiuje tego rodzaju świadomość jako: zbiór szeroko rozpowszechnionych i akceptowanych w danej zbiorowości poglądów, idei i przekonań, które stają się wzorcami czy schematami myślenia wpajanymi jej członkom i egzekwowanymi przez społeczny nacisk ${ }^{7}$. Z. Hull zwraca uwagę dwa wymiary świadomości ekologicznej: indywidualny i zbiorowy. W wymiarze indywidualnym oznacza ona przeżywanie i sposób myślenia przez jednostki o sferze przyrodniczej, w wymiarze zbiorowym natomiast, odnosi się do standardów pojmowania, przeżywania i wartościowania biosfery ${ }^{8}$. Opisując elementy konstytuujące świadomość ekologiczną, autor ten wskazał na:

- wiedzę ekologiczną, obejmującą: znajomość procesów zachodzących w ekosferze i poszczególnych ekosystemach, wiedzę o zależnościach i wzajemnych powiązaniach stanowiących o równowadze ekosystemu, wiedzę o zależnościach między różnymi sferami działalności człowieka a środowiskiem oraz wiedzę o zagrożeniach środowiskowych;

${ }^{5}$ The Norwegian Ministry of the Environment organized a symposium on sustainable production and consumption in 1994, http://www.iisd.ca/consume/oslo000.html, [dostęp: 10.09.2017].

${ }^{6}$ Zob. F. Bylok, Konsument, konsumpcja i społeczeństwo konsumpcyjne we współczesnym świecie, Śląsk, Katowice 2013.

7 P. Sztompka, Socjologia. Analiza spoleczeństwa, Znak, Kraków 2002, s. 307.

${ }^{8}$ Z. Hull, Świadomość ekologiczna (II), „Aura” 1984, nr 11, s. 3-4. 
- wyobraźnię ekologiczną, umożliwiającą przewidywanie ekologicznych skutków podejmowanych działań (zdolność całościowego widzenia i ujmowania powiązań pomiędzy działaniami człowieka a procesami przyrodniczymi);

- biocentrycznie zorientowany system wartości i norm oraz ocen etyki ekologicznej ${ }^{9}$.

Źródeł modernizacji ekologicznej upatruje się dziś z jednej strony w staraniach globalnych korporacji, krajowych i międzynarodowych struktur politycznych, $\mathrm{z}$ drugiej strony - w indywidualnych wysiłkach konsumentów na zatomizowanym rynku. W efekcie rośnie zainteresowanie organizacji (komercyjnych i publicznych) wdrażaniem koncepcji zrównoważonego rozwoju i społecznej odpowiedzialności. Pojawiają się też propozycje rozwijania tzw. ekologicznego obywatelstwa, jako wspólnego osobistego zaangażowania na rzecz zrównoważonego rozwoju ${ }^{10}$. Według A. Dobsona obywatele ekologiczni poczują odpowiedzialność za środowisko w skali całej planety i podejmą w swoim codziennym życiu działania, mające na celu ograniczenie negatywnego wpływ na inne osoby i środowisko przyrodnicze. Stanie się to możliwe między innymi za sprawą rozważania konsekwencji własnych rutynowych decyzji o zakupach. Do głównych przejawów ekologizacji indywidualnej konsumpcji można zaliczyć racjonalne wykorzystywanie dóbr, ograniczanie konsumpcji tych produktów, w produkcji których są wykorzystywane nieodnawialne surowce naturalne i wytwarzane odpady groźne dla środowiska, racjonalną gospodarkę zapasami, rezygnację z dóbr jednorazowego użytku, a wykorzystywaniu dóbr wielokrotnego użytku, czy wreszcie korzystanie z produktów używanych i dalsze przekazywanie ich innym konsumentom ${ }^{11}$.

\section{Przegląd literatury}

Różne czynniki wpływają na odpowiedzialną konsumpcję. Są to zarówno czynniki indywidualne, jak i społeczne oraz sytuacyjne. Czynniki indywidualne obejmują m.in. cechy społeczno-ekonomiczne (wiek, płeć, wykształcenie i dochód), potrzeby i pragnienia, wartości, nawyki, styl życia. Na czynniki społeczne składają się normy społeczne, osadzone w kontekście kulturowym, a także w środkach masowego przekazu. Z kolei czynniki sytuacyjne odnoszą się do sytuacji zakupu (np. widoczności produktów na półkach handlowych), zachęt

\footnotetext{
${ }^{9}$ Ibidem, s. $3-4$.

${ }^{10}$ Zob. A. Dobson, Citizenship and the Environment, Oxford University Press, Oxford 2003.

${ }^{11}$ E. Kieżel (red.), Konsument i jego zachowania na rynku europejskim, Polskie Wydawnictwo Ekonomiczne, Warszawa 2010, s. 188.
} 
do zakupu (np. zachęt finansowych) oraz dostępności produktów zrównoważonych $^{12}$. Z badań odpowiedzialnej konsumpcji wynika, że dla konsumentów mniej zamożnych najważniejsza jest niższa cena, w mniejszym stopniu zwracają oni uwagę na aspekt etyczny. Jak zauważają Carrigan i Attalla, konsumenci kupują produkty nieetyczne wtedy, gdy ich cena jest zdecydowanie niższa niż produktów uważanych za etyczne ${ }^{13}$. J. Mariański pisze o relatywizmie moralnym w podejściu do konsumpcji etycznej, którego efektem są różne postawy i zachowania wobec różnych produktów ${ }^{14}$. I tak w przypadku produktów związanych z modą i pozycją społeczną (np. odzieży, obuwia i kosmetyków) wizerunek marki ma pierwszeństwo nad kryteriami etycznymi. Z kolei w przypadku produktów żywnościowych wytworzonych w sposób nieetyczny (np. stosowanie GMO, nieetyczne zabijanie zwierząt, nieetyczne postępowanie ze zwierzętami, stosowanie antybiotyków) konsumenci w większym zakresie stosują różne formy bojkotu.

Warto w tym miejscu nawiązać do wyników badania przeprowadzonego w 2013 r. przez A. Burgiel. Jego celem była identyfikacja stosunku polskich konsumentów do konsumpcji wspólnej (ang. sharing economy), czyli pożyczania, dzielenia się, przekazywania niepotrzebnych rzeczy oraz zakupu i odsprzedaży używanych rzeczy, stanowiącej niewątpliwie przejaw odpowiedzialnej konsumpcji. Z $\mathrm{Z}$ badań tych wynika, że kobiety wykazują nieco bardziej pozytywne nastawienie niż mężczyźni wobec oddawania niepotrzebnych rzeczy, dokonywania zakupu rzeczy używanych i dzielenia się z innymi. Stwierdzono też, że wykształcenie badanych różnicuje ich stosunek do sprzedaży i zakupu rzeczy z drugiej ręki oraz pożyczania. Respondenci z wykształceniem średnim i wyższym mają bardziej pozytywne postawy niż osoby gorzej wykształcone wobec odsprzedaży i zakupu rzeczy używanych ${ }^{15}$.

\section{Metodyka badań}

Przeprowadzone przez autorkę badania miały charakter pilotażowy sondażowy bezpośredni ze źródeł pierwotnych. Ich celem była identyfikacja postaw wobec

${ }^{12} \mathrm{~W}$. Terlau, D. Hirsch, Sustainable Consumption and the Attitude-Behaviour-Gap Phenomenon - Causes and Measurements towards a Sustainable Development, http://centmapress. ilb.uni-bonn.de [dostęp: 20.08.2017].

${ }^{13}$ M. Carrigan, A. Attalla, The Myth of The Ethical Consumer - Do Ethics Matter in Purchase Behaviour?, „Journal of Consumer Marketing” 2001, nr 18 (7), s. 564.

${ }^{14}$ J. Mariański, Społeczeństwo i moralność. Studia z katolickiej nauki społecznej i socjologii moralności, Biblios, Tarnów 2008, s. 219.

${ }^{15}$ A. Burgiel, Postawy konsumentów wobec zachowań z zakresu konsumpcji wspólnej - czy ekonomia współdzielona ma szanse na upowszechnienie?, Studia i Prace WNEiZ Uniwersytetu Szczecińskiego 2016, nr 44/2, s. 36. 
ochrony środowiska naturalnego oraz praktykowanych działań prośrodowiskowych. Na potrzeby badania sformułowano następujące pytania:

1. Jaki jest poziom świadomości ekologicznej respondentów? W szczególności, czy posiadają oni wiedzę i wyobraźnię ekologiczną?

2. Jakiejest ich poczucie sprawczości w zakresiepodejmowanych indywidualnie działań na rzecz środowiska?

3. Jakie są najważniejsze kryteria dokonywania zakupów? Jaką pozycję w tym zbiorze zajmują kryteria prośrodowiskowe i prospołeczne?

4. Jakie działania na rzecz środowiska podejmują respondenci w swoim codziennym życiu? Jaką rolę odgrywa w tych działaniach dekonsumpcja kolaboratywna i wtórne wykorzystanie produktów?

Szukając odpowiedzi na powyższe pytania, starano się określić czy, a jeżeli tak, to w jaki sposób, płeć respondenta wpływa na jego stosunek do opisanych w pytaniach kwestii.

W ramach doboru celowego respondentów wytypowano studentów trzech wydziałów Uniwersytetu Ekonomicznego we Wrocławiu, tj. Wydziału Nauk Ekonomicznych (NE), Wydziału Zarządzania i Finansów (ZF) oraz Wydziału Inżynieryjno-Ekonomicznego (IE). W pomiarze pierwotnym zastosowano ankietę audytoryjną jako metodę zbierania danych oraz kwestionariusz jako instrument pomiarowy. Pytania w kwestionariuszu podzielono na cztery części, bezpośrednio związane $z$ odpowiedziami na pytania badawcze, oraz pytania metryczkowe. Pytania pierwszej części kwestionariusza miały umożliwić określenie poziomu świadomości ekologicznej respondentów, w tym poczucie sprawczości w zakresie podejmowanych indywidualnie działań na rzecz środowiska. W drugiej części znalazły się trzy pytania sondujące znaczenia dla badanych osób kryteriów prośrodowiskowych i prospołecznych w procesie nabywania dóbr. W pierwszej i drugiej części zastosowano skalę pomiarową porządkową. Respondenci oceniali swoje postawy i zachowania, korzystając z pięciostopniowych skal natężenia opisanych werbalnie (nie zgadzam się, raczej nie zgadzam się, trudno powiedzieć, raczej zgadzam się, zgadzam się). Przyjęto, że wybór odpowiedzi: „zgadzam się” świadczy o wysokim poziomie świadomości, „raczej zgadzam się” - średnim, „raczej nie zgadzam się" - o niskim, a „nie zgadzam się” o bardzo niskim poziomie świadomości ekologicznej respondentów. W trzeciej i czwartej części kwestionariusza skupiono się na identyfikacji głównych kryteriów stosowanych przez respondentów przy nabywaniu dóbr oraz podejmowanych przez nich działaniach na rzecz środowiska. W tym przypadku zastosowano pytania wielokrotnego wyboru, aczkolwiek lista możliwych odpowiedzi miała charakter zamknięty.

W procesie diagnozowania uwarunkowań postaw i zachowań proekologicznych, ograniczono się wyłącznie do analizy wpływu takich czynników jak wiek, płeć i wykształcenie. W procesie porządkowania danych wykorzystano metody statystyki opisowej, takie jak: liczebności i proporcje. Do prezentacji danych uży- 
to metody graficznej w postaci wykresów umożliwiających jednoczesne ukazanie struktury wyników pomiaru we wszystkich badanych aspektach odpowiedzialnej konsumpcji, z uwzględnieniem płci respondenta.

\section{Prezentacja wyników badania pilotażowego}

Badanie przeprowadzono w kwietniu 2018 r. Wzięło w nim udział łącznie 320 respondentów.

Tabela 1. Struktura próby badawczej $(\mathrm{N}=320)$

\begin{tabular}{|c|c|c|c|c|c|c|}
\hline \multirow{2}{*}{ Wydzial } & \multicolumn{4}{|c|}{ Pleć } & \multicolumn{2}{c|}{ Wiek } \\
\cline { 2 - 6 } & \multicolumn{2}{|c|}{ K } & \multicolumn{2}{c|}{ M } & K & M \\
\hline NE & 151 & $62,4 \%$ & 47 & $60,3 \%$ & & \\
\hline ZF & 49 & $20,2 \%$ & 22 & $28,2 \%$ & \multirow{2}{*}{$18-24$} & $18-24$ \\
\hline IE & 42 & $17,4 \%$ & 9 & $11,5 \%$ & & 78 \\
\hline SUMA & 242 & $100 \%$ & 78 & $100 \%$ & 242 & 78 \\
\hline
\end{tabular}

Legenda: $\mathrm{K}$ - kobiety, M - mężczyźni

Źródło: opracowanie własne

Wiek wszystkich badanych osób mieścił się w przedziale 18-24 lata. Badane osoby to studenci różnych lat i poziomów edukacji (pierwszy i drugi stopień), kierunków: Zarządzanie, Międzynarodowe Stosunki Gospodarcze, Finanse i Rachunkowość. Kobiety stanowiły 75,6\% a mężczyźni 24,4\% badanych respondentów. Większość badanych osób (zarówno w grupie kobiet jak i mężczyzn) to studenci Wydziału Nauk Ekonomicznych (w sumie 61,9\% badanej populacji) (tab. 1). Należy zaznaczyć, iż na wszystkich wymienionych wydziałach studenci zetknęli się z problematyką zrównoważonego rozwoju i ochrony środowiska w trakcie realizacji takich przedmiotów jak: Zarządzanie, Nauka o przedsiębiorstwie, Ekonomika i organizacja przedsiębiorstwa.

W pierwszej części kwestionariusza respondenci poproszeni zostali o ustosunkowanie się do pięciu stwierdzeń, obrazujących stosunek do kwestii ochrony środowiska. Na pierwsze pytanie - czy zgadza się Pani/Pan ze stwierdzeniem: „Interesuję się tematyką ochrony środowiska naturalnego" - w sumie 54,6\% kobiet odpowiedziało, że raczej zgadza się lub zgadza się z tym stwierdzeniem. Wśród mężczyzn ten odsetek był niższy i wyniósł $41 \%$. Odpowiedzi „nie zgadzam się” lub „raczej nie zgadzam się” udzieliło 19,6\% kobiet i 29,5\% mężczyzn. Odsetek odpowiedzi „trudno powiedzieć” był zbliżony u obu płci i wynosił $25,7 \%$ u kobiet i $29,5 \%$ u mężczyzn (rys. 1). 


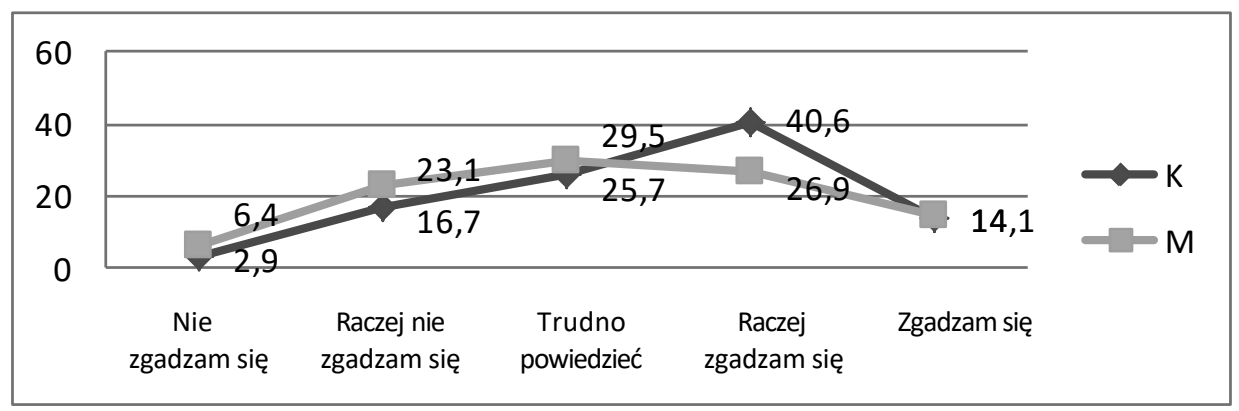

Rys. 1. Procentowy udzial odpowiedzi na pytanie o stosunek do stwierdzenia: „Interesuję się tematyką ochrony środowiska naturalnego"

Źródło: opracowanie własne

W drugim pytaniu konieczne było ustosunkowanie się do stwierdzenia: „Mam poczucie zagrożenia kryzysem ekologicznym”. Zarówno wśród kobiet, jak i mężczyzn najwięcej było odpowiedzi „raczej zgadzam się” (odpowiednio $42,1 \%$ i 44,9\%). Na drugim miejscu wśród kobiet znalazła się odpowiedź „trudno powiedzieć" $(23,1 \%)$, natomiast mężczyźni bardziej skłaniali się ku odpowiedzi „raczej nie zgadzam się" (20,5\%). Nie zgodziło się z tym stwierdzeniem 3,7\% kobiet i 5,1\% mężczyzn. Odpowiedź „trudno powiedzieć” wybrało 29,5\% mężczyzn i 25,7\% kobiet (rys. 2).

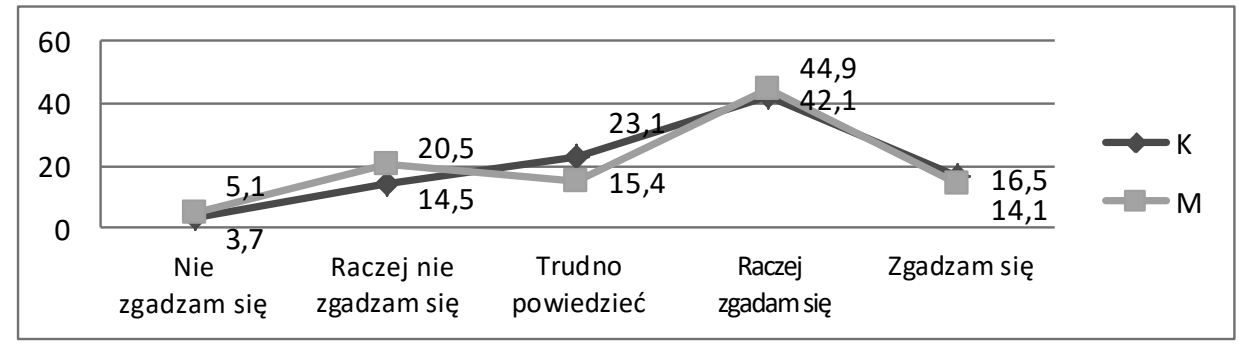

Rys. 2. Procentowy udzial odpowiedzi na pytanie o stosunek do stwierdzenia: „Mam poczucie zagrożenia kryzysem ekologicznym"

Źródło: opracowanie własne

Kolejne pytanie kwestionariusza wymagało oceny stwierdzenia: „Nie aprobuję degradacji środowiska naturalnego". Ponad połowa kobiet wybrała odpowiedź ,zgadzam się” (52,1\%). U mężczyzn ta opcja odpowiedzi również cieszyła się największą popularnością (46,2\%). Na drugim miejscu u obu płci znalazła się odpowiedź „raczej zgadzam się” (odpowiednio 30,2\% - kobiety, 34,6\% - mężczyźni). Tylko nieliczni nie zgodzili się z tym stwierdzeniem (1,7\% kobiet i $2,6 \%$ mężczyzn) (rys. 3). 


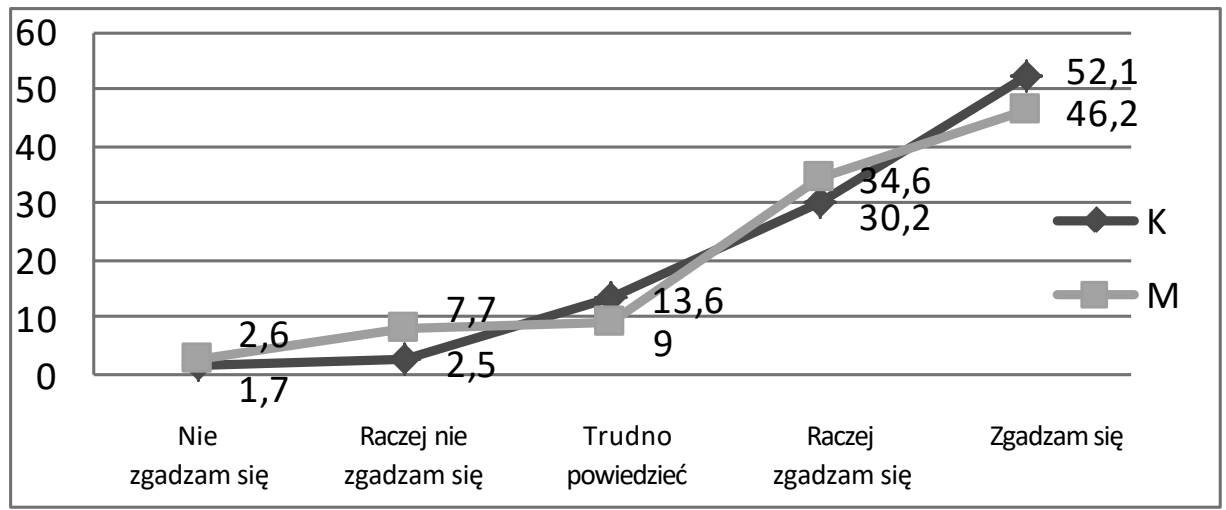

Rys. 3. Procentowy udzial odpowiedzi na pytanie o stosunek do stwierdzenia: „Nie aprobuję degradacji środowiska naturalnego"

Źródło: opracowanie własne

Kolejne pytanie wymagało od respondentów zastanowienia się, czy dostrzegają relacje między ochroną praw człowieka i ochroną środowiska. W odpowiedzi na to pytanie kobiety najczęściej wybierały opcję „raczej zgadzam się" (38\%), a następnie „trudno powiedzieć” (34,3\%). W przeciwieństwie do kobiet, najwięcej mężczyzn decydowało się na odpowiedź „trudno powiedzieć” (39,7\%), a w drugiej kolejności - „raczej zgadzam się” (34,6\%). Najmniej wskazań odnotowano przy odpowiedzi „nie zgadzam się” (1,7\% - kobiety, 6,4\% - mężczyźni) (rys. 4).

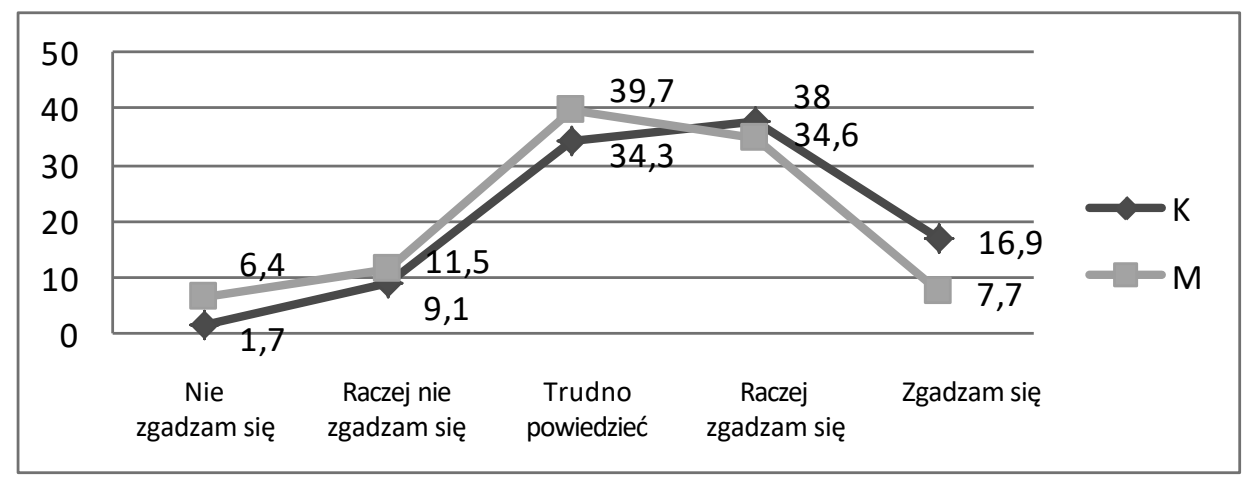

Rys. 4. Procentowy udział odpowiedzi na pytanie o stosunek do stwierdzenia: „Dostrzegam relacje między ochroną praw czlowieka i ochroną środowiska"

Źródło: opracowanie własne

Ostatnie pytanie pierwszej części kwestionariusza odnosiło się do poczucia sprawczości indywidualnie podejmowanych działań na rzecz środowiska. Kobiety najczęściej wskazywały odpowiedzi „,raczej zgadzam się” (36,8\%) i ,zgadzam się” 
(28,9\%). Z kolei u mężczyzn na pierwszym miejscu znalazła się odpowiedź „raczej zgadzam się" $(35,9 \%)$, a na drugim „trudno powiedzieć” (33,3\%). Zaledwie $1,2 \%$ kobiet i 5,1\% mężczyzn stwierdziło, że nie zgadza się ze stwierdzeniem, iż podejmowanie indywidualnych działań na rzecz środowiska jest skuteczne. Odpowiedź „trudno powiedzieć” wybrało 33,3\% mężczyzn i 19,8\% kobiet (rys. 5).

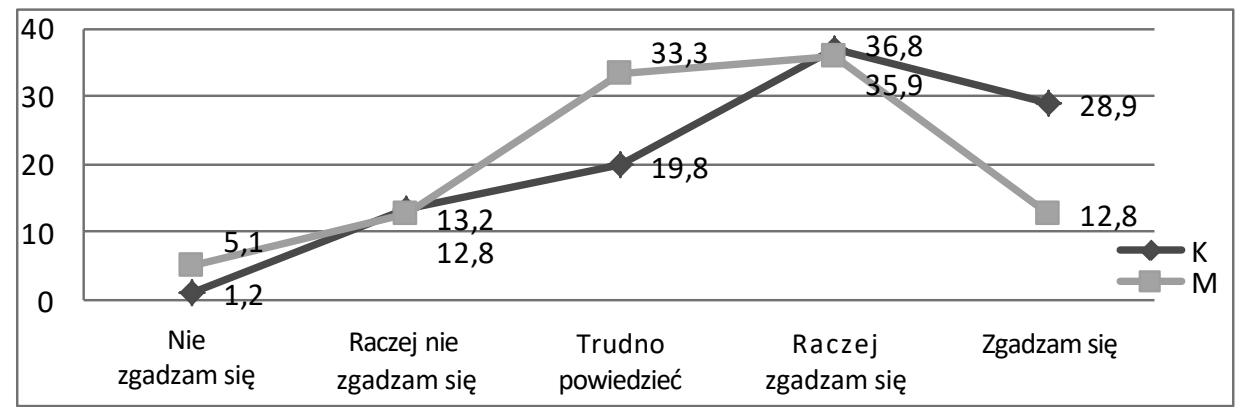

Rys. 5. Procentowy udzial odpowiedzi na pytanie o stosunek do stwierdzenia: „Podejmowanie indywidualnych działań na rzecz środowiska jest skuteczne”

Źródło: opracowanie własne

W drugiej części kwestionariusza znalazły się trzy pytania służące zdiagnozowaniu znaczenia dla respondentów - w procesie nabywania dóbr - kryteriów prośrodowiskowych. Zbiorcze zestawienie odpowiedzi na te pytania zawiera tabela 2.

Tabela 2. Rozkład odpowiedzi na pytanie o kryteria nabywania dóbr*

\begin{tabular}{|l|c|c|c|c|c|c|c|c|c|c|c|}
\hline \multicolumn{1}{|c|}{$\begin{array}{c}\text { Czy zgadza się Pani/ } \\
\text { Pan z następującymi } \\
\text { stwierdzeniami }\end{array}$} & \multicolumn{2}{c|}{$\begin{array}{c}\text { Nie } \\
\text { zgadzam się }\end{array}$} & $\begin{array}{c}\text { Raczej nie } \\
\text { zgadzam się }\end{array}$ & \multicolumn{2}{c|}{$\begin{array}{c}\text { Trudno } \\
\text { powiedzieć }\end{array}$} & \multicolumn{2}{c|}{$\begin{array}{c}\text { Raczej } \\
\text { zgadzam się }\end{array}$} & \multicolumn{2}{c|}{$\begin{array}{c}\text { Zgadzam } \\
\text { się }\end{array}$} \\
\cline { 2 - 12 } & K & M & K & M & K & M & K & M & K & M \\
\hline $\begin{array}{l}\text { Przy nabywaniu dóbr } \\
\text { biorę pod uwagę rodzaj } \\
\text { materiału/surowca, } \\
\text { z którego zostały } \\
\text { wytworzone }\end{array}$ & 5,4 & 15,4 & 16,1 & 23,1 & 16,9 & 17,9 & 44,6 & 26,9 & 16,9 & 16,7 \\
\hline $\begin{array}{l}\text { Przy nabywaniu dóbr } \\
\text { biorę pod uwagę } \\
\text { warunki, w jakich zostały } \\
\text { wytworzone }\end{array}$ & 8,3 & 26,9 & 24,8 & 35,9 & 34,7 & 19,2 & 24,8 & 16,7 & 7,4 & 1,3 \\
\hline $\begin{array}{l}\text { Przy nabywaniu dóbr biorę } \\
\text { pod uwagę wpływ, jaki } \\
\text { wywiera na środowisko } \\
\text { i otoczenie społeczne ich } \\
\text { użytkowanie i utylizacja }\end{array}$ & 6,2 & 20,5 & 24,8 & 28,2 & 33,5 & 23,1 & 29,8 & 23,1 & 5,8 & 5,1 \\
\hline
\end{tabular}

* liczby podane w tabeli wyrażone są w procentach 
Badania pokazały, że rodzaj materiału z którego wytwarzane są produkty, brany jest pod uwage przez 61,5\% kobiet (odpowiedzi „raczej zgadzam się” i „zgadzam się"). W grupie mężczyzn suma odpowiedzi pozytywnych („raczej zgadzam się" i ,zgadzam się") wyniosła 43,6\%. W obu grupach respondentów najrzadziej wskazywaną opcją odpowiedzi było „nie zgadzam się” (5,4\% - kobiety, 15,4\% - mężczyźni).

Pytanie o to, czy przy nabywaniu dóbr bierze respondent pod uwagę warunki, w jakich zostały one wytworzone (np. poszanowanie praw człowieka, uczciwe warunki pracy i płacy, dbałość o dobrostan zwierząt), okazało się pytaniem dość kłopotliwym dla kobiet - 34,7\% zaznaczyło opcję „trudno powiedzieć”, „raczej nie zgadzam się” i „raczej zgadzam się” - po 24,8\%. Mężczyźni odznaczali się większym zdecydowaniem i najczęściej wybierali odpowiedź „raczej nie zgadzam się" (35,9\%) bądź „nie zgadzam się" (26,9\%). Zaledwie 7,4\% kobiet i 1,3\% mężczyzn zgodziło się ze sformułowanym w pytaniu stwierdzeniem.

Poszukując odpowiedzi na ostatnie pytanie tej części kwestionariusza, respondenci zastanawiali się, czy nabywając dobra, biorą pod uwagę wpływ, jaki ich użytkowanie i utylizacja wywiera na środowisko i otoczenie społeczne. Podobnie jak we wcześniejszym pytaniu najwięcej kobiet $(33,5 \%)$ wybrało opcję „trudno powiedzieć” i „raczej zgadzam się” (29,8\%). W przypadku mężczyzn najwięcej wskazań odnotowano przy odpowiedzi „raczej nie zgadzam się”.

W trzeciej części kwestionariusza skupiono się na identyfikacji głównych kryteriów stosowanych przy nabywaniu dóbr. Respondenci poproszeni zostali o wskazanie trzech najważniejszych dla nich kryteriów spośród siedmiu. Z badania wynika, że zarówno dla kobiet, jak i mężczyzn trzema najważniejszymi kryteriami są: cena, bezpieczeństwo użytkowania i znana marka. Kryteriami o najmniejszym znaczeniu okazały się zgodność z normami etycznymi obowiązującymi w danym społeczeństwie oraz przyjazność dla środowiska naturalnego i społecznego (rys. 6).

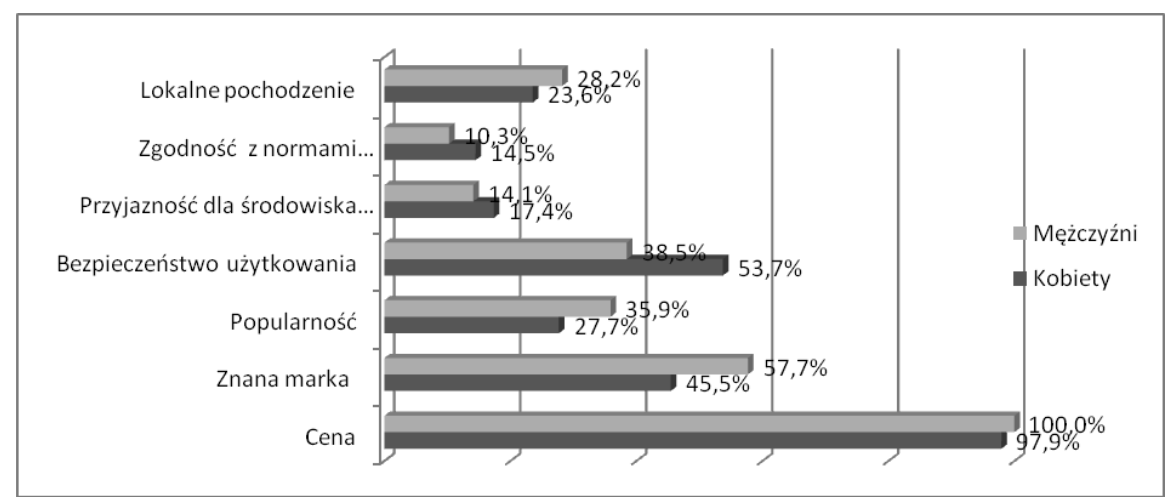

Rys. 6. Kryteria stosowane przez respondentów przy nabywaniu dóbr **

** pytanie wielokrotnego wyboru, wyniki nie sumują się do 100\%. Respondenci wybierali trzy najważniejsze kryteria spośród siedmiu wskazanych w pytaniu

Źródło: opracowanie własne 
Wśród działań prośrodowiskowych praktykowanych w codziennym życiu (rys. 7) obie grupy respondentów wskazywały najczęściej: oszczędne korzystanie z wody i energii elektrycznej, segregowanie śmieci oraz ograniczanie ilości nabywanych i konsumowanych dóbr na rzecz ich jakości. Najrzadziej podejmowaną inicjatywą okazało się korzystanie z energii odnawialnej. Słabo rozpowszechniona była też dekonsumpcja kolaboratywna w postaci wspólnego użytkowania dóbr. Największe różnice między dwoma badanymi grupami ujawniły się w odniesieniu do spożycia mięsa i wtórnego wykorzystania rzeczy i materiałów powszechnego użytku. Podczas gdy 34,3\% kobiet ogranicza spożycie mięsa, to wśród mężczyzn jest to już zaledwie 7,7\%. Kobiety częściej niż mężczyźni przyznają się też do wtórnego wykorzystywanie rzeczy (45,5\% kobiet, 26,9\% mężczyzn).

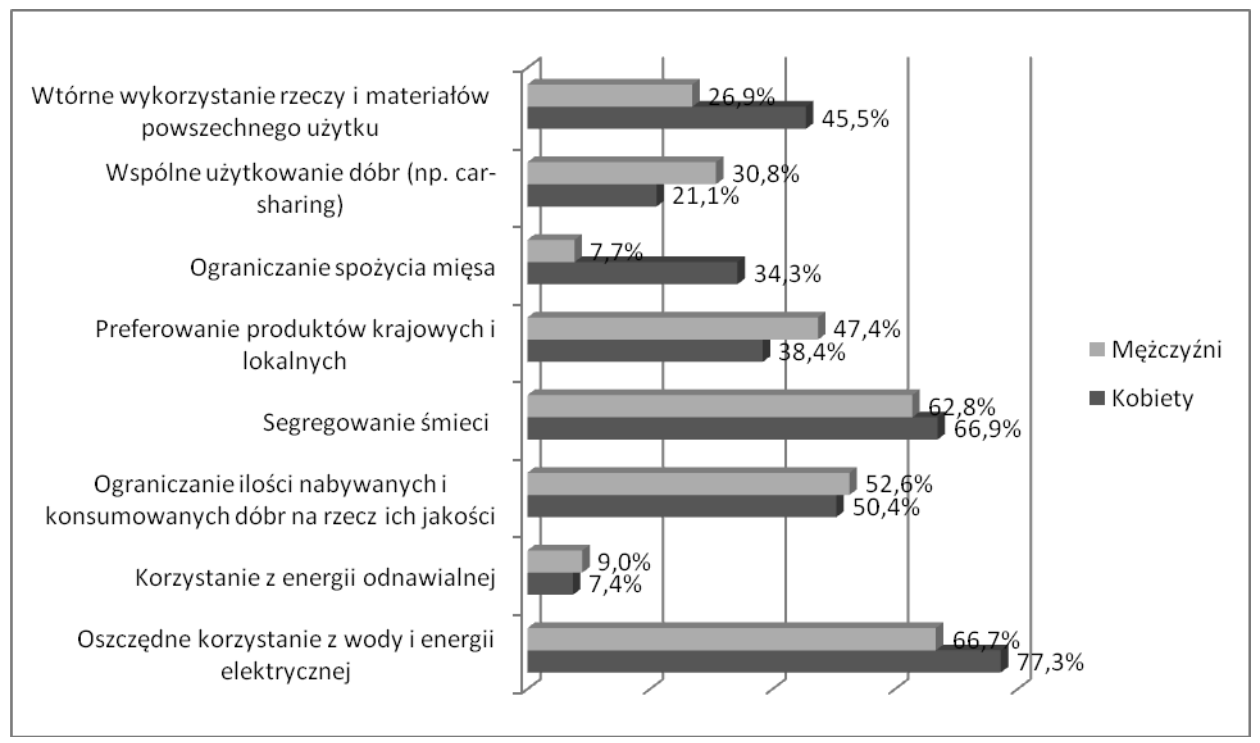

Rys. 7. Podejmowane przez respondentów dzialania prośrodowiskowe $\mathrm{e}^{* *}$

** pytanie wielokrotnego wyboru, wyniki nie sumują się do $100 \%$

Źródło: opracowanie własne

\section{Podsumowanie i wnioski}

$\mathrm{Na}$ wstępie należy zaznaczyć, iż z powodu istotnych ograniczeń zrealizowanych badań, wynikających między innymi z zasad doboru i rozmiaru próby, nie można ich traktować jako reprezentatywnych i rozstrzygających. Tym niemniej dają one pewnie wyobrażenia na temat, słabo rozpoznanych w literaturze przedmiotu, kwestii postaw i zachowań proekologicznych konsumentów. 
Przeprowadzone badania umożliwiły sformułowanie następujących wniosków:

1. Dominujący udział odpowiedzi „raczej zgadzam się” wskazuje na średni poziom świadomości ekologicznej respondentów.

2. Mężczyzn cechuje niższy niż w przypadku kobiet poziom świadomości ekologicznej (niższy udział odpowiedzi „raczej zgadzam się” i ,zgadzam się" w I części kwestionariusza). Posiadają mniejszą wiedzę i wyobraźnię ekologiczną, w rezultacie słabiej niż kobiety odczuwają zależności i powiązania między działaniami człowieka a procesami przyrodniczymi.

3. Poczucie sprawczości indywidualnych działań proekologicznych jest wyższe u kobiet.

4. Obie grupy respondentów podobnie postrzegają istotność kryteriów nabywania produktów; kryteria prośrodowiskowe postrzegane są jako mniej istotne.

5. Nie stwierdzono istotnych różnic miedzy kobietami i mężczyznami w zakresie podejmowanych na rzecz środowiska działań; wyjątek w tym względzie stanowi stosunek respondentów do ograniczania spożycia mięsa oraz wtórnego wykorzystywania dóbr, które to działania częściej praktykowane są przez kobiety.

Sformułowane wyżej wnioski opierają się wyłącznie na deklaracjach respondentów, które tylko w ograniczonym stopniu zostały poddane wersyfikacji $\mathrm{w}$ procesie badawczym. Tymczasem, jak pokazały badania przeprowadzone w 2005 roku przez GfK Polonia - instytut badania opinii, rynku i konsumpcji na reprezentatywnej grupie 1000 Polaków, respondenci przeceniają swoją wiedzę na temat środowiska naturalnego ${ }^{16}$. P. Zieliński określił to zjawisko jako ,[...] wyraźne rozdzielenie między ja-idealnym (przekonanie o własnej wysokiej świadomości ekologicznej) a ja-realnym [...]"17, czyli faktycznym poziomem tej świadomości.

Poziom świadomości ekologicznej badanych studentów stanowi niewątpliwie wyzwanie dla Uniwersytetu Ekonomicznego we Wrocławiu. Konieczne wydaje się podjęcie wysiłków na rzecz odpowiedniego konstruowania programów nauczania, służącego skutecznej edukacji ekologicznej. Edukacja tego rodzaju powinna być zorientowana nie tylko na upowszechnienie informacji o produktach i skutkach ich stosowania dla środowiska, ale także na zmianę świadomości, kształtowanie postaw i rozwijanie wrażliwości ekologicznej. A wszystko po to, aby $\mathrm{z}$ jednej strony pomóc studentom dostrzec nadmierne antropogenne obciążenie środowiska, $z$ drugiej - wyzwolić w nich chęć i potencjał do podejmowania twórczych inicjatyw służących ochronie biosfery.

${ }^{16}$ GfK Polonia, Badanie świadomości ekologicznej Polaków. Raport dla Bayer Sp. z o.o. Październik 2005. http://www.eduskrypt.pl (2008).

${ }_{17}$ P. Zieliński, Wyzwanie edukacyjne: zmiana świadomości ekologicznej warunkiem ciagłości gatunku ludzkiego, „Podstawy Edukacji” 2009, t. 2, s. 355-356. 
Zaprezentowane badania cechuje znaczny poziom ogólności. Mają one wyłącznie deskryptywny charakter, stąd potrzeba ich pogłębienia. Nieodzowne wydaje się przeprowadzenie badań eksplikacyjnych, mających na celu wyjaśnienie przyczyn opisanych zjawisk. Dalsze badania w zakresie tytułowej problematyki powinny umożliwić udzielenie odpowiedzi na następujące pytania: Czy, a jeżeli tak, to w jaki sposób, kryteria zakupu, ich waga różnią się w zależności od rodzaju nabywanego dobra? Jakie są główne bariery w podejmowaniu działań o charakterze prośrodowiskowym? W jaki sposób różne czynniki, zarówno indywidualne, jak też społeczne i sytuacyjne, oddziałują na zdolność i gotowość do podejmowania inicjatyw na rzecz środowiska?

\section{Bibliografia}

Burgiel A., Postawy konsumentów wobec zachowań z zakresu konsumpcji wspólnej - czy ekonomia wspótdzielona ma szanse na upowszechnienie?, Studia i Prace WNEiZ Uniwersytetu Szczecińskiego 2016, nr 44/2.

Bylok F., Konsument, konsumpcja i społeczeństwo konsumpcyjne we wspótczesnym świecie, Śląsk, Katowice 2013.

Bywalec Cz., Rudnicki L., Konsumpcja, Polskie Wydawnictwo Ekonomiczne, Warszawa 2002.

Carrigan M., Attalla A., The Myth of The Ethical Consumer - Do Ethics Matter in Purchase Behaviour? „Journal of Consumer Marketing” 2001, nr 18 (7).

Dobson A., Citizenship and the Environment. Oxford University Press, Oxford 2003.

GfK Polonia, Badanie świadomości ekologicznej Polaków. Raport dla Bayer Sp. z o.o. Październik 2005. http://www.eduskrypt.pl (2008).

Hull Z., Świadomość ekologiczna (II), „Aura” 1984, nr 11.

Kieżel E. (red.), Konsument i jego zachowania na rynku europejskim, Polskie Wydawnictwo Ekonomiczne, Warszawa 2010.

Mariański J., Społeczeństwo i moralność. Studia z katolickiej nauki społecznej i socjologii moralności, Biblios, Tarnów 2008.

Sztompka P., Socjologia. Analiza społeczeństwa, Znak, Kraków 2002.

Terlau W., Hirsch D., Sustainable Consumption and the Attitude-Behaviour-Gap Phenomenon - Causes and Measurements towards a Sustainable Development, http://centmapress.ilb.uni-bonn.de [dostęp: 20.08.2017].

The Norwegian Ministry of the Environment organized a symposium on sustainable production and consumption in 1994, http://www.iisd.ca/consume/oslo000.html [dostęp: 10.09.2017].

Tkaczyk St., Kołuda J., Nowe trendy konsumenckie a sukces organizacji, „Zeszyty Naukowe Uniwersytetu Przyrodniczo-Humanistycznego w Siedlcach”, nr 97, Seria: Administracja i Zarządzanie (24) 2013.

UNEP, Planning for change: Guidelines for national programmes on sustainable consumption and production. United Nations Environment Programme 2008.

Zieliński P., Wyzwanie edukacyjne: zmiana świadomości ekologicznej warunkiem ciagłości gatunku ludzkiego, „Podstawy Edukacji ”2009, t 2. 


\section{Streszczenie}

Celem artykułu była identyfikacja postaw wobec ochrony środowiska naturalnego oraz praktykowanych działań prośrodowiskowych. W opracowaniu starano się odpowiedzieć na następujące pytania: Jaki jest poziom świadomości ekologicznej respondentów? W szczególności, czy posiadają wiedzę i wyobraźnię ekologiczną? Jakie jest ich poczucie sprawczości w zakresie indywidualnie podejmowanych działań na rzecz środowiska? Jakie są najważniejsze kryteria dokonywania zakupów? Jakie pozycję $\mathrm{w}$ tym zbiorze zajmują kryteria prośrodowiskowe i prospołeczne? Jakie działania na rzecz środowiska podejmują respondenci w swoim codziennym życiu?

Aby odpowiedzieć na powyższe pytania, przeprowadzono badanie sondażowe bezpośrednie ze źródeł pierwotnych wśród studentów trzech wydziałów Uniwersytetu Ekonomicznego we Wrocławiu. Badania pokazały, że respondentów cechuje średni poziom świadomości ekologicznej, przy czym u mężczyzn zarówno poziom tej świadomości, jak też poczucie sprawczości indywidualnych działań proekologicznych, są nieznacznie niższe niż u kobiet. I badane kobiety, i mężczyźni podobnie hierarchizują kryteria nabywania produktów. Kryteria prośrodowiskowe postrzegane są przez nich jako mniej istotne. Nie stwierdzono istotnych różnic miedzy kobietami i mężczyznami w zakresie podejmowanych na rzecz środowiska działań.

Słowa kluczowe: odpowiedzialna konsumpcja, zrównoważony rozwój, świadomość ekologiczna

Numer klasyfikacji JEL: O13, Q56 